International Journal of Social Science and Economic Research

ISSN: 2455-8834

Volume: 05, Issue: 01 "January 2020"

\title{
SETTING AGENDA WITH TREPIDATION: THE MEDIA AND TERRIFYING NEWS FROM NIGERIA'S ELECTORAL “BATTLEFIELD"
}

\author{
${ }^{1}$ Mike OMILUSI, PhD; ${ }^{2}$ Benedict Kayode IMOUKHUEDE \\ ${ }^{1}$ Department of Political Science, Ekiti State University, Nigeria \\ ${ }^{2}$ Department of Public Administration, Rufus Giwa Polytechnic, Owo, Ondo State
}

DOI: 10.46609/IJSSER.2020.v05i01.006 URL: https://doi.org/10.46609/IJSSER.2020.v05i01.006

\begin{abstract}
The media are at the center of the democratic process, and their situation can be used as a barometer for testing the depth of political change. The essential roles of the media in a democracy include periodic civic education, election monitoring, reporting political activities and disseminating election results. Suffice to say that civic education is fundamental to democracy because it includes strengthening participation in civil society as well as setting up programs to enhance civic behavior. The contribution of this essay to the existing literature is twofold. One is to examine the nature and character of agenda setting with which the media in Nigeria is engaged during electioneering and the effects of this on voting behaviour in particular and electoral politics in general. Two is to interrogate the nexus between the language of election reportage and electoral violence in the country.
\end{abstract}

Keywords: Media, Agenda Setting, News, Battlefield, Electioneering

\section{INTRODUCTION AND PROBLEM STATEMENT}

The essential roles of the media in a democracy include periodic civic education, election monitoring, reporting political activities and disseminating election results. Suffice to say that civic education is fundamental to democracy because it includes strengthening participation in civil society as well as setting up programs to enhance civic behavior. Commonly referred to as the -Fourth Estate of the Realm, the media, as observed by Heywood (2007:231), function as an integral part of the political process, as -communication lies at the heart of politics. The mass media, both print and electronic, have important roles to play in enlightening the politicians and citizens, exposing miscreants - no matter how well or highly placed - who will not respect the laws of the land and the sovereignty of the citizens; set agendas for politicians and parties to address in their campaigns, and to enlighten the citizens to make good electoral choices, and to 


\section{International Journal of Social Science and Economic Research}

ISSN: $2455-8834$

Volume: 05, Issue: 01 "January 2020"

impartially report the activities of parties (Iruonagbe et al, 2013:19). These roles may also include formal voter education material provided by the electoral management body; alternatively, or additionally, the media themselves may produce their own voter education materials. The overall aim of media coverage during elections campaigns in democracies is fair and objective reporting and information dissemination. This can, for instance, be achieved through measures such as a just allocation of broadcasting time between all the competing parties and candidates, (voluntary) agreements on fair news programmes, reports, and non-news programmes, or debates between party leaders (ACE Encyclopedia, 2012).

Elections in democratic states across the world have become standard and acceptable procedure for democratic leadership and constitutional governance (Jendele, 2011; McChesney, 2015). Generally, elections are usually expected to be periodic, inclusive, definitive as well as free and fair. Its basic objective is to select the official decision makers who are supposed to represent citizen's interests. The successful conduct of democratic elections requires the existence of an independent electoral process that will safeguard the sanctity of the electoral process. It is generally acknowledged that the mass media is vested with a big responsibility during any election in a democratic context (McQuail, 2000). According to Gambari (2015 cited in Rural Reporters, March 25) the role of the media in promoting peaceful elections, unity and cohesion of the nation- state includes a firm commitment to investigative journalism; refraining from sensational, provocative and inciting reportorial language; demonstrating high sense of patriotism while reporting on election issues in order not to undermine national security and image; and ensuring fairness in their news reporting.

The will of the people provides the basis for the authority of government, and in turn the government must guarantee the free expression of the will of the voters through genuine elections. The right to seek, receive and impart information concerns the right of the electors to gain and share knowledge and opinions necessary to form their will regarding the electoral competitors, whether they are candidates, political parties or those supporting or opposing propositions put forth in referenda. It also concerns the freedom of the news media to cover issues they deem to be significant to the public debate surrounding elections (Merloe, 2008:14). Thus, media coverage is a crucial component of elections that makes extra demands on the professional and ethical conduct of the journalist and the media as an industry. It is of vital importance that journalists handle election processes in a manner that is fair, just, equitable and innovative (IPC, 2014:1). The contribution of this essay to the existing literature is twofold. One is to examine the nature and character of agenda setting with which the media in Nigeria is engaged during electioneering and the effects of this on voting behaviour. Two is to interrogate the nexus between the language of election reportage and electoral violence in the country. 
International Journal of Social Science and Economic Research

ISSN: $2455-8834$

Volume: 05, Issue: 01 "January 2020"

\section{THE MEDIA, NEWS REPORTAGE AND POLITICAL VIOLENCE: A THEORETICAL EXPLORATION}

The role of the media in preventing electoral violence is crucial. Media can spur on violence, or encourage peace. Media can propagate rumors or debunk them. News reporting plays a particularly critical role in defusing violence risks and establishing the legitimacy of the process. However, the role of the media in promoting electoral violence cannot be separated from the political culture of the country. Indeed, it is often a crude reflection of the simmering grievances that characterize societies that are profoundly unequal, ethnically divided and lacking in responsive and accountable government (Hennemeyer, 2014:106). The role of the media in preventing electoral violence is crucial as it can increase the population's potential to mobilise and also to dispute false rumours that have the potential to cause violence. Increasing situational awareness at a local level with social media and traditional media such as local radio could help mitigate electoral violence. According to Ekeanyanwu (2007), the media exists as an organ of information sourcing and dissemination, educational promotion, surveillance, social enlightenment and mobilization. These functions set the media apart as an important link/factor in the relationship between the government and the governed and make them a sine qua non to societal growth and development.

Mass media are normatively expected to provide relevant, diverse, pluralistic, and carefully investigated information to the public. Harold Lasswell (1969) itemizes three functions performed by the mass media, namely, surveillance of the world to report on-going events, interpretation of the meaning of events, and socialization of individuals into their cultural settings. Another attribute of the media is the deliberate manipulation of the political process. The manner in which these functions are performed, it is argued, affects the lives of individuals, groups, and social organizations, as well as the course of domestic and international politics. In the same vein, Lucian Pye (1963) points out that there is a 'peculiarly intimate relationship between the political process and the communication process.' Frere (2009) argues that:

For an electoral process to qualify as "free" and "fair," not only must the election unfold in adequate political and administrative conditions, but citizens must also have access to sufficient information about the parties, candidates and voting procedures to ensure that they will make an enlightened and valid choice. Elections will only be "free" if all parties can express themselves: candidates, political parties, citizens, civil society and, of course, journalists

Media is however, sometimes manipulated by the governing party (especially if the media is state-owned) to report in their favour. Manipulation can take place during the designing of the programmes, reports and news, discussion programmes, and even non-news programmes, such 


\section{International Journal of Social Science and Economic Research}

ISSN: $2455-8834$

Volume: 05, Issue: 01 "January 2020"

as pure entertainment shows and movies. Propaganda may be disseminated under the guise of objective public information by the government. The danger of misuse of government power for campaigning purposes can be limited if laws and regulations are in place to regulate the role of the media in the elections campaign (ACE Encyclopedia, 2012). It is observed that whatever programs and polices do get discussed in debates, the press tends to downplay them in favor of discussions of "winners and losers." Rather than asking if the candidates' pronouncements hold water, journalists are more apt to analyze how each side prepared, how it came across in the heat of the battle, and especially how its future chances were affected. The media are encouraged in this postmortem analysis by "spin doctors," campaign aides who immediately after the debate appear in interviews and press conferences to clarify or emphasize certain points, to explain away damaging statements, and especially to insist that their candidate won.

Violent conflicts are obstacles to the conduct of free, fair and peaceful elections as they could lead to voters' apathy and hinder the free performance of media roles and responsibilities during electoral processes (IPC, 2014:4). It is observed that elections do not necessarily cause violence, but the process of competing for political power often exacerbates existing tensions and escalates them into violence. Election-related violence is special as the strategic intent and practical consequences of violent acts are designed to in some way to affect the process of election processes (Sisk, 2008 cited in Rao, 2014:2). They are often designed to disable and disrupt opposing forces, so as to win; to undermine the integrity and legitimacy of elections all together; or to influence voting behaviour through threats and intimidation. According to Robert (1999:8), elections are a more civilized way to choose leaders, but in a country with a small but divided elite, the losers of an election might find themselves without alternative means of employment. Indeed, some unsuccessful politicians find themselves in exile or prison. This, plus the lack of experience with compromise might explain why elections are particularly difficult in transitional countries, and why it takes time for leaders to learn how to play the rules of the electoral game.

The media of course plays very central and critical role in all democracies being the chief purveyor of information that citizens rely upon to make informed decisions and judgements. As part of civil society their conduct or misconduct can impact heavily on democracy and democratic processes. The actions or inactions of journalists can also impact positively or negatively on the democratic health of a country depending on the way and manner issues are reported (IPC, 2014:1). Apart from political constraints, other factors such as commercialization and decline of journalists' professional ethics principally caused by the daily strife for survival in a highly competitive but limited market, affected the role of the press as the fourth estate (Adjovi, 2002; Abati, 1998).

While states with a sanguine attitude towards the media have created an environment for journalists and media organizations to build and or enhance their capacity as active voices in and 


\section{International Journal of Social Science and Economic Research}

Volume: 05, Issue: 01 "January 2020"

vessels for democratic discourses, in the public sphere, their brutal, intolerant and dictatorial counterparts have succeeded in eroding the capacity of media practitioners to champion democratic causes (Tetty, 2008:21). In a bid to retain power at all cost, these elites in government may even visit their authoritarian tendencies on the media, particularly when it becomes too critical or vociferous of their policies, which, most often are obnoxious. For instance, for almost two weeks in June 2014 in Nigeria, the government, through the military, embarked on what seemed like a general clampdown on independent media. Commencing from Friday, June 6, 2014, the Nigerian military and agents of the government oppressed, harassed, impounded, detained and restrained the distribution vehicles of some media houses in the country. Without any provocation, soldiers invaded newspapers distribution centers in Abuja and other major Nigerian cities confiscating and destroying thousands of copies of different newspapers. The measures were said to be based on intelligence report that some newspaper distribution vehicles were being used to convey arms, ammunition and other explosive devices to terrorists (Omilusi, 2015).

The media clampdown came days after the government, through the then information minister, Labaran Maku, warned the media not to give "free publicity," saying they must "define the lines between the urge to report and the need to protect the interest of our nation" (See TNV, June 7, 2014). Security agents used the pretext of the insurgency to threaten, harass, detain, and seize the equipment of journalists. Yet, section 22 of the constitution imposes an obligation on the mass media. That section states that the press, which includes newspapers, magazines, radio, televisions and other agencies of the mass media shall at all times be free to uphold the fundamental objectives contained in chapter two of the constitution and uphold the responsibility and accountability of the government to the people. The clampdown was therefore, seen as a breach of the Nigerian constitution and a stark reminder of dark days of military despotism in the country.

\section{SETTING AGENDA WITH TREPIDATION: THE REPORTER AS EYEWITNESS TO HISTORY}

The defining feature of watchdog journalism is not the political stance of the reporter, story, or media outlet, but rather the role of asking hard or probing questions of the powerful to maximize transparency and to serve the public interest. On a routine basis, timely and accurate information provided by news coverage of public affairs should help citizens evaluate the performance of political leaders and parties (Norris and Odugbemi, 2010:17). Thus, one of the most important roles of the journalist during the campaign period is as an "agenda-setter", a person who helps define the issues and explain them to the electorate in understandable ways. In many cases, the issues in the campaign will be self-evident. They are the major issues facing the nation and the electorate (Andresen, n.d:4). Schaffner (2006) posits that citizens' ability to acquire and utilize 


\section{International Journal of Social Science and Economic Research}

ISSN: $2455-8834$

Volume: 05, Issue: 01 "January 2020"

information about electoral processes would serve as useful instruments of accountability before, during and after elections. Press organisations are supposed to be the most reliable public information sources but situations in different countries dictate otherwise. As suggested by Baran and Davies (2003), agenda setting empirically demonstrates links between media exposure, audience motivation to seek orientation, and audience perception on issues. The agenda setting theory implies that the mass media pre-determine what issues are regarded as important at any given time in a given society. This theory, however, does not ascribe to the media power to determine what the public actually thinks, but to them the power to determine what the people should be thinking about.

Many of the vulnerabilities plaguing the media in Africa, and, indeed, developing countries in general, are structural, whether related to pay, training or equipment. Poorly-paid journalists tend to value job security over the quest for truth; they are willing to write whatever they can get paid to produce. Poorly trained journalists lack the skills to research their stories, present them in a logical form and balance competing opinions. Poorly-equipped journalists lack the tools and budgets to produce professional stories (Hennemeyer, 2014:98). Inevitably, journalistic culture is shaped as much by external factors as by internal rationale: the institutional environment within which journalists operate, market competition, legal constraints and particular political climates may be considered the predominant external influences (Stamper and Brants, 2011:113). Following extensive commercialization and the subsequent segmentation of audiences, journalists have taken on more varied roles. First, the increasing competition in the media landscape has forced journalists to respond to the logic of the market and to take the needs and interests of their audiences more seriously into account when covering political issues (Brants and Voltmer, 2011:9).

Journalism which is concerned with news coverage and reporting has often been seen as a tool for promoting and ensuring either hatred or peace among political parties, religious organizations and communities (Aghadiegwu and Ogbonna, 2015:2). For election purposes, Journalists tend to come from a range of backgrounds. Some have joined media organisations as young cadets, with or without first obtaining a university degree; some are autodidacts who have written or broadcast their way into a professional journalism job. Some have university-level journalism education; others have received a number of on-the-job short courses; and some have received no formal training at all (ACE Encyclopedia, 2012). White (2014:2) argues that Journalists have the right to report unpopular ideas, even opinions that might shock, offend or disturb their audience, though they need to be careful when reporting offensive or inflammatory opinions particularly from public figures, such as politicians or community leaders. Today, in most countries that have undergone a democratic transition since the 1980s, the press is an important player on the political stage. Journalists are often feared by politicians because they have succeeded in 


\section{International Journal of Social Science and Economic Research}

ISSN: $2455-8834$

Volume: 05, Issue: 01 "January 2020"

uncovering corruption, the abuse of power and assorted malfeasance. They are also relentlessly wooed because a bad press can mean the end of a political career (Coronel, n.d:3).

The journalist as watchdog is a role that is defined differently across countries and cultures. That definition is fluid, often contingent on the existing social, political, and economic conditions, and a reflection as much of the historical moment as it is of preexisting structures and media cultures. Journalists are inspired by liberal democratic notions of the press as watchdog, but they draw from the well of their own culture and history as well (Coronel, 2010:123). From the Enlightenment forward, free and independent media have been recognized as the sina qua non of civil society. More recently, multiple observers have noted that governments are more responsive to public needs in countries with an active press - a contention famously made by the Nobel Prize- winning economist Amartya Sen (See Moeller, 2010:68). In an effort to enhance campaign coverage, and provide a snapshot of voter sentiment during the pre-election period, broadcast news organizations often conduct public opinion polls, and report the results of polls conducted by others (Andresen, n.d:4). As watchdogs, it is argued, the news media should serve democracy by providing a check and balance on powerful sectors of society, including leaders within the public and private domains. This represents the classic notion of the news media as the fourth estate, counterbalancing the power of the executive, legislative, and judiciary branches. According to this well-known ideal, the news media should keep a skeptical eye on the powerful, guarding the public interest and protecting it from incompetence, corruption, and misinformation (Norris and Odugbemi, 2010:16).

Ordinarily, electoral processes help establish what issues are before the community. They help define which are priority issues, and present various options to respond to those challenges. Campaigns thus set agendas with candidates articulating their priority issues (UNDP, n.d:3). Nigeria has the unenviable problem of mass media pessimism and sometimes, member of the public unwittingly follow such lead by speculating without concrete proof, that there would be violence at a particular election because such election was too close to call based on the heated political atmosphere of the electoral campaign (Laseinde, 2015).

Nigeria operates a mixed mass media system -government controlled and private ownership. The electronic media are largely in the hands of Government-Federal and State, with few privately owned broadcast stations. The print media are dominated by private ownership, with very few owned by State Government. Until 1992 when the then military government headed by General Ibrahim Babangida deregulated the broadcast industry, electronic media in Nigeria were all owned and controlled by Federal and State Government. With this media mix, it is easy to understand why news contents in the Nigerian mass media often reflect the pattern of ownership (Obot, 2013). Though the media play a vital role in the functioning of democratic societies, as they substantively inform citizens about politics (Picard 1998; Croteau and Hoynes 2001), they- 


\section{International Journal of Social Science and Economic Research}

ISSN: $2455-8834$

Volume: 05, Issue: 01 "January 2020"

especially privately owned media- are also economically driven institutions and need to behave in an economically rational manner. These two conflicting tasks-contributing to the functioning of democracy and being commercially successful-challenge media companies to find a balance "between the public interest and their own financial self-interest" (Picard 1998:337).

Suffice it to note that Journalists and media outlets always operate in a given social, political and economic context that affects their interpretation of reality and the filters used to select what is 'important' and how it is presented to the public. Thus, several factors exist that influence professionals when they produce news and present it according to a given framework or approach. These include their personal experiences, their orientation (ideological, political or religious), journalistic routines, the parameters and measures of the media organization, and even the format in which the news is presented (Llanos and Nina, 2011:9). There is a common saying with regards to mass media control in Nigeria and elsewhere, which has become a cliché, that "He who pays the piper dictates the tune". This means that the owners of a mass media channel controls what the medium broadcasts and how it broadcasts it.

The 2015 general elections were Nigeria's fourth since the return to civil rule in 1999. The elections of 2003, 2007 and 2011 followed the transitional elections conducted by the departing military regime in 1999. However, these elections, like the ones before them, had been dogged with bitter controversies and grievances on a national scale resulting from violence and fraud that have characterized Nigeria's electoral history (Orji and Uzodi, 2012). It is a truism therefore, that electioneering in Nigeria is seen as an equivalent of war and political parties/gladiators, as the combatants. In fact, the horrendous language being used to describe election by the media in Nigeria creates fear in many prospective voters. Words like "violence", "war" and "battlefield" have been entrenched in news reportage, feature stories and columns as if they are irreversible permanent features of the country's electoral process. The next section will expatiate the trend particularly as it relates to the last general elections in the country.

\section{THE LANGUAGE OF ELECTION REPORTAGE IN NIGERIA}

Though a growing body of research suggests that political disaffection is very complex and it is an oversimplification to only blame news media for voter malaise (Austin and Pinkleton, 1995; Pinkleton and Austin, 2002) but in view of the fact that, most electorates, across board, learn about the choices they face in elections not from political contact with politicians but predominantly from the mass media (Tador, 2014:2), one can begin to imagine the level of negative impact such sensational media hypes would have had on the voters in previous elections conducted in Nigeria.

Journalistic coverage, for example, provides a filtering mechanism that is often regarded by the public as a more trustworthy, reliable, and authoritative source of information than more partisan 
channels. In using the mass media, however, parties are obviously more restricted in their control, since they have to work with journalists, broadcasters, editors, and news executives, who process party messages according to independent frameworks of presentation and analysis (Norris, 2005:5). In Africa countries, where political differences and their attendant tensions can create highly volatile political situations, the media have a significant role in curbing those potentials. This was demonstrated during the postelection violence that engulfed Kenya. While the media were not able to prevent the eruption, spread and continuation of violence, they did make a conscious effort not to exacerbate the situation. They did this by bringing to the fore perspectives that aimed at claiming tempers and promoting reconciliation among the various factions (Tetty, 2008:15).

Past electoral violence in Nigeria has been fuelled by acts or rumours of electoral fraud and the perception that authorities have a partisan bias. Media outlets are often seen as partisan and lack objectivity and credible platforms to counter rumours. Journalists usually adopt sensational and panic-stricken news during electioneering, perhaps to attract members of the public or as a marketing strategy such that, as earlier indicated, electoral activities are portrayed in horrendous manner. This, no doubt, dampens the morale of prospective voters. Examples of terrifying headlines are cited below:

\begin{tabular}{|l|l|}
\hline \multicolumn{1}{|c|}{ News Headlines } & \multicolumn{1}{|c|}{ Medium } \\
\hline Bayelsa Poll Threatened by Same Old Electoral Evils & The Punch, November 28, 2015 \\
\hline Battle for Kogi, Bayelsa & The Nation, October 28, 2015 \\
\hline $\begin{array}{l}\text { Orgy of Violence Continues as Bayelsa Rerun Election } \\
\text { Holds Today }\end{array}$ & CKN Nigeria, January 9, 2016 \\
\hline $\begin{array}{l}\text { Election Violence Fears: Politicians, CEOs Move } \\
\text { Families Abroad }\end{array}$ & The Punch, January 17, 2015 \\
\hline Scores of APC Members Killed in Rivers, 100 Arrested & Daily Times, March 28, 2015 \\
\hline 58 killed in Pre-Election Violence in 60 Days -NHRC & The Punch, February 14, 2015 \\
\hline $\begin{array}{l}\text { Divided Northern Nigerian City Fears Post-Election } \\
\text { Violence }\end{array}$ & $\begin{array}{l}\text { Latest Business, March 27, } \\
2015\end{array}$ \\
\hline 2015: Battle for Southwest & The Nation, July 9, 2014 \\
\hline
\end{tabular}


International Journal of Social Science and Economic Research

ISSN: $2455-8834$

Volume: 05, Issue: 01 "January 2020"

\section{IMPLICATIONS ON THE ELECTORAL PROCESS}

The realties are that, where the media is controlled by the State or large (not necessarily impartial) business houses or individuals, opposition party candidates and parties, poorer candidates and political parties are at a disadvantage. To cover such costs candidates must be independently wealthy or be able to call upon rich patrons to bank-roll them (KadirgamarRajasingham, 2005). The reality, however, is that the media in new and restored democracy do not always live up to the ideal. They are hobbled by stringent laws, monopolistic ownership, and sometimes, the threat of brute force. State controls are not the only constraints. Serious reporting is difficult to sustain in competitive media markets that put a premium on the shallow and sensational. Moreover, the media are sometimes used as proxies in the battle between rival political groups, in the process sowing divisiveness rather than consensus, hate speech instead of sober debate, and suspicion rather than social trust. In these cases, the media contribute to public cynicism and democratic decay (Coronel, n.d:3). Media magnates have used their newspapers or broadcast stations to promote their business interests, cut down their rivals, and in other ways advance their political or business agenda. State ownership, meanwhile, allows government functionaries to clamp down on critical reporting and recalcitrant reporters and enables the government to propagate its unchallenged views among the people (ibid:8).

In the coverage of politics and elections, the greatest challenge of the Nigerian media is that proprietors who are mostly persons with political interests discourage them from adhering to the fundamental principles of balance and objectivity (Aghamelu, n.d:169). It is observable that the media are owned by the elite and deployed principally to advance their interest within the society. Apart from the profit motive which propels investments into the ownership of media houses, a major critical motive for media ownership is its use as a negotiating chip in inter-elite power game The cardinal social responsibility of the media, which ought to be owed the society in general was transferred to the elite on account of such factors as media ownership structure, commercialistic interest, dominant interest of the elite and overriding power of the state. The resultant effect is the enthronement of the culture of impunity and total disregard of the rule of law in government and governance (Nwozor, 2014:98).

The media are universally referred to as agents of power and political control, such that those who hold sway of political power and authority are always conscious of the fact that information management and control is central to the capturing, retention and exercise of political power. The larger implication of this is that the ownership, control and accessibility to the media are considered to be critical to the wielding and sustenance of political power. This recognition of the role of mass media as agents of power and political control is partly responsible for the 


\section{International Journal of Social Science and Economic Research}

ISSN: $2455-8834$

Volume: 05, Issue: 01 "January 2020"

decision of the governments of developing countries (Nigeria inclusive) to either own their own media or regulate news and information flow within and into their countries (Sussman: 1989 cited in Ibraheem et al, 2015).

Media, in both traditional and social media forms has considerable influence in either promoting or reducing conflict. Media reporting has great potential for creating or exacerbating already existing tension, which is already particularly heightened around election time (Nigeria Peace and Security Working Group, 2015:10). News media is tightly entwined with the attention economy. Newspapers try to capture people's attentions through headlines. TV and radio stations try to entice people to not change the channel. And, indeed, there is a long history of news media leveraging fear to grab attention, often with a reputational cost. Yellow journalism tarnished newspapers' credibility with scary headlines intended to generate sales. The history of radio and television is sullied with propaganda as political ideologues leveraged social psychology to shape the public's opinion (Boyd, 2012:2).

\section{CONCLUSION}

It is the position of this essay that elections are essential in a democracy and are fundamental features of representative democracy. When free, fair and transparent, they confer credibility and legitimacy on the outcome. Similarly, contemporary notions of democracy provide that every citizen has the right to seek public office and participate. Omotola (2013:178) argues that the effective functioning and sustenance of democratic society largely depends on the institutionalization of key elements, such as the constitutional opening of democratic political space so that no "rights" group is denied access to participation in the democratic process, and citizens, regardless of their identities, have multiple avenues for the expression and representation of their interests and values. This, it should be added, can be sustained/facilitated by free, virile and non-partisan press. Deducing from the foregoing, it is glaring that the media has an important role in democratic governance. Because election is one of the pillars of democracy, our focus has, therefore, been on how the media can engender peaceful and credible electioneering as opposed to its current fearful reportage feature in Nigeria.

Thus, it must be stated that best practices in media coverage of elections can contribute towards a larger media literacy education campaign, to enhance citizens' awareness and abilities to reflect critically upon the information before them. Such a project would bring together media professionals and expert researchers on media in elections to identify international standards for election news reporting, and best examples to be shared (Semetko, 2010:189). Similarly, a legal framework for democratic elections must address several issues related to the media: protections for the media to exercise freedom of expression in the electoral context; providing electoral contestants with a genuine opportunity to communicate their electoral messages to the public; 


\section{International Journal of Social Science and Economic Research}

ISSN: $2455-8834$

Volume: 05, Issue: 01 "January 2020"

and providing the electorate with accurate information upon which to make decisions about voting choices (Merloe, 2008:49).

Arogundade (quoted in The Guardian, March 1, 2015) imposes some important social obligations on the media which include "the need to provide equitable access to parties and candidates, the need to project the voices of underrepresented groups including women, youths and persons living with disabilities, the need to shun hate and inciting speech, the need to reject offensive advertorials, the need to be professional and ethical at all times and the need to accord higher priority to the public interest as against narrow interests". As we fully embrace a networked society, we need to consider what guiding principles should influence decisions about the spread of information. For Egbala (2014), in reporting to avert conflict, the media should as much as possible try to adhere to the social responsibility theory. This places the interest of the society first. He argues that if the media observes its agenda setting role, it will give direction to the public on how to handle the issues of election and thus avert or help in managing electoral conflict. In order to ensure that the media is given a free rein in the quest to promote good governance, The Dakar Declaration of May 32005 calls on member states of UNESCO:

1. To ensure that government bodies respect the principles of transparency, accountability and public access to information in their operations

2. To respect the function of the news media as an essential factor in good governance, vital to increasing both transparency and accountability in decision making processes and to communicating the principles of good governance to the citizenry

3. To create an enabling environment in which an independent, sustainable, pluralistic and professional media sector can flourish

4. To transform State and government media into public service media and to guarantee their editorial and financial independence

5. To guarantee the independence of regulatory bodies for broadcasting and their role in promoting media diversity, including through community media outlets

6. To provide for comprehensive legal guarantees for the right to access information; recognizing the right to access information held by all public bodies, and requiring them to publish key categories of information and to introduce effective systems of record management, and to ensure proper implementation in practice of these guarantees

7. To promote wide public awareness of legislation and policies regarding access to information held by public bodies

8. To follow the principle that legislative bodies should be open to the public 


\section{International Journal of Social Science and Economic Research}

ISSN: $2455-8834$

Volume: 05, Issue: 01 "January 2020"

9. To support broad public participation in the processes of governance, including through such means as ICTs and e-governance

10. To assist the news media in providing professional coverage of elections by ensuring full and timely disclosure of information to journalists and by guaranteeing political parties fair access to the media throughout the electoral process

11. To repeal criminal defamation laws and laws that give special protections to officials and institutions

12. To act to put an end to killing of, attacks on, harassment of, arrests and jailing of journalists, including those investigating corruption, and to make all reasonable efforts to bring those responsible to justice

13. To guarantee the right of journalists to protect their confidential sources of information 14 . To take effective collective and individual action to hold to account those governments that actively repress the media

Also, media organisations should work closely with civil society to raise awareness of voters on electoral and political processes. Reporting around elections should be sensitive to conflict dynamics so that reporting does not intensify tensions that already exist. They should also use their platforms to promote nonviolence and in the event of violence breaking out, proactively host on air or publish those with influence to call for peace (Nigeria Peace and Security Working Group, 2015:11). Just as societies are dependent on information to enable citizenry, societies can be undermined and fragmented through fear. There is nothing neutral about the practice of reporting and it behooves journalists to draw from anthropologists and reflexively account for how their work affects the communities they serve. Capturing people's attention is critical, but increasing societal fear in order to capture attention has significant consequences that must be considered. Journalists and news agencies have an ethical responsibility to account for the externalities of their reporting (Boyd, 2012:3).

\section{REFERENCES}

Abati, R. (1998) 'Press Freedom in Nigeria: 1859-1998', in Atere, A. A and Olagbemi, A. eds., Communication, Language and Culture in Society, Lagos: Bolaji and Associates.

ACE Encyclopedia (2012) Media and Elections, The ACE Electoral Knowledge Network, Available at: https://aceproject.org/ace-en/topics/me/mef/mef01

ACE Encyclopedia (2012) Parties and Candidates, The ACE Electoral Knowledge Network, Available at: $\underline{w w}$.aceproject.org 


\section{International Journal of Social Science and Economic Research}

ISSN: $2455-8834$

Volume: 05, Issue: 01 "January 2020"

Adjovi, E. V. (2002) 'Liberté de Presse et Corruption au Bénin - la Dérive du Journalisme de Marché', Working Paper, No. 10, Mainz University: Department of Anthropology and African Studies

Agekameh, Dele (2015) The South-South Conundrum, The Nation, November 4

Aghadiegwu, Ukwueze and Ogbonna, Uche A. (2015) The Rise of Hate and Peace Journalism in The Nigerian Democratization Process: The Place of the New Media, Communication Panorama African and Global Perspectives, Volume 1 Number 1 Sept-Oct 2015 Maiden Issue

Aghamelu, Fidelis Chuka (n.d) The Role of the Mass Media in the Nigerian Electoral Process, Unizik Journal of Arts and Humanities

Andresen, Robert (n.d) Campaign and Election Reporting, Available at: http://www.maldivesinfo.gov.mv/home/upload/downloads/election.pdf

Arogundade, Lanre (2015) Report of elections coverage launched, The Guardian, March 1

Austin, E.W. and Pinkleton, B. E. (1995) Positive and negative effects of political disaffection on less experienced voters, Journal of Broadcasting and Electronic Media, $39,215-235$

Baran, S.J and Davis, D.K (2003) Mass Communication Theory: Foundations, Ferment and Future, United States, Thomson and Wadsworth

Boyd, Danah (2012) The Ethics of Fear and How it Undermines an Informed Citizenry, Available at: http://www.poynter.org/2012/fear-undermines-an-informed-citizenry-asmedia-struggles-with-attention-economy/192509/

Brants, Kees and Voltmer, Katrin (2011) "Introduction” in Brants and Voltmer (eds.) Political Communication in Postmodern Democracy: Challenging the Primacy of Politics, New York, Palgrave Macmillan

Coronel, Sheila C. (2010) "Corruption and the Watchdog Role of the News Media", in Norris, Pippa (ed.) Public Sentinel: News Media \& Governance Reform, The International Bank for Reconstruction and Development / The World Bank, Available at: http://siteresources.worldbank.org/EXTGOVACC/Resources/PublicSentineleBook.pdf

Coronel, Sheila C. (n.d) The Role of The Media In Deepening Democracy

Croteau, David, and Hoynes, William (2001) The business of media: corporate media and the public interest. Thousand Oaks, CA: Pine Forge Press 
International Journal of Social Science and Economic Research

ISSN: $2455-8834$

Volume: 05, Issue: 01 "January 2020"

Egbala, Samuel (2014) 2015 Elections: The Responsibility of the Media and Journalists in Managing Conflicts, The Nigerian Observer, December 15

Ekeanyanwu, N. T. (2007). The Nigerian Press Coverage of Political Conflicts in a Pluralistic Society, Global Media Journal, Vol. N0.1, Pp 64-91, Accessible from www.sun.ac.za/gmja

Frère, Marie-Soleil (2009b), After the Hate Media: Regulation in the DRC, Burundi and Rwanda, in: Global Media and Communications, Vol5, No 3, 327-352

Hennemeyer, Christian (2014) "Media and Electoral Violence" in Elections Worth Dying for? A Selection of Case Studies from Africa, International Foundation for Electoral Systems

Heywood, A. (2007) Politics. New York: Palgrave Macmillan

Ibraheem, I.A et al (2015) Beyond Influence: Media and the 2015 Presidential Election,

IPC (2014) Overview of the Media (Newspapers \& Online) Monitoring Report of the Nigerian Press Council (NPC) and The International Press Centre (IPC) for November and December, 2014 and Matters Arising, Available at: http://www.ipcng.org/en/download/media_monitoring_report/Overview\%20of\%20media $\% 20$ monitoring\%20report\%20for\%20November\%20and\%20December\%20and\%20matt er\%20arising.pdf

Iruonagbe, Tunde et al (2013) A Conceptual Review Of Mass Media And Political Violence In Nigeria Between 1999 and 2013, New Media and Mass Communication, Vol.20, 2013

Jendele, H. (2011) Talking to the Polls: Power, Time and the Politics of the Representation in Two South Africa Radio Talk Shows, African Studies, vol. 70

Kadirgamar-Rajasingham, Sakuntala (2005) Essentials of Free and Fair Elections, A Paper presented at Regional Dialogue on Free, Fair and Credible Elections Islamabad, Pakistan Organized by PILDAT 29-30 June 2005

Laseinde, C.L (2015) The Role of the Federal Government of Nigeria in Providing Security Before During and After the February 2015 Elections

Lasswell, H. D. (1969) "The Structure and Function of Communication in Society,' in W. Schramm (ed.), Mass Communications. Urbana: University of Illinois Press

Llanos, Beatriz and Nina, Juana (2011) Election Coverage from a Gender Perspective: A Media Monitoring Manual, International Institute for Democracy and Electoral Assistance 
International Journal of Social Science and Economic Research

ISSN: $2455-8834$

Volume: 05, Issue: 01 "January 2020"

McChesney, R.W. (2015). „The Personal is Political: The Political Economy of the NonCommercial Radio Broadcasting in the United States". Monthly Review

McQuail, Dennis (2000) Mass Communication Theory. 4th Edition, London, Sage Publications

Merloe, Patrick (2008) Promoting Legal Frameworks for Democratic Elections: An NDI Guide for Developing Election Laws and Law Commentaries, National Democratic Institute for International Affairs (NDI) Available at: https://www.ndi.org/files/2404_ww_elect_legalframeworks_093008.pdf

Moeller, Susan (2010) "Media Coverage of Natural Disasters and Humanitarian Crises" in Norris, Pippa (ed.) Public Sentinel: News Media \& Governance Reform, The International Bank for Reconstruction and Development / The World Bank, Available at: http://siteresources.worldbank.org/EXTGOVACC/Resources/PublicSentineleBook.pdf

Nigeria Peace and Security Working (2015) Nigeria Elections and Violence: Synthesis of the National Picture and Regional Dynamics and Recommendations for Action, 19th January 2015

Norris, Pippa and Odugbemi, Sina (2010) "Evaluating Media Performance" in Norris, Pippa (ed.) Public Sentinel: News Media \& Governance Reform, The International Bank for Reconstruction and Development / The World Bank, Available at: http://siteresources.worldbank.org/EXTGOVACC/Resources/PublicSentineleBook.pdf

Nwozor, Agaptus (2014) Redefining Political Terrorism: Nigerian Media and the Crisis of Democratization, African Research Review, Vol. 8 (2) Serial No. 33, April, 2014 Pp. 96117

Obot, Charles (2013) Mass Media Electioneering Campaign and Uyo (Nigeria) Voters' Decision During 2011 General Elections, Journal of Politics and Law, Volume: 6. Issue: 1 March 2013

Omotola, Shola (2013:177) Trapped in Transition? Nigeria's First Democratic Decade and Beyond, Taiwan Journal of Democracy, Volume 9, No. 2: 171-200

Orji, O. and Uzodi, N. (2012) The 2011 Post Election Violence in Nigeria. Abuja: Policy and Legal Advocacy Centre

Picard, Robert (1998) "Media Concentration, Economics and Regulation" in The Politics of News, The News of Politics, Doris Graber, Denis McQuail \& Pippa Norris (eds.),(pp. 193-217), Washington D.C.: CQ Press 
International Journal of Social Science and Economic Research

ISSN: $2455-8834$

Volume: 05, Issue: 01 "January 2020"

Pye, L. (ed.) (1963) Communication and Political Development. Princeton, N. J.: Princeton University Press

Rao, Sumedh (2014) Dealing with Election-Related Violence in Fragile and Conflict-Affected States, GSDRC Helpdesk Research Report 1126. Birmingham, UK: GSDRC, University of Birmingham. http://www.gsdrc.org/go/display\&type=Helpdesk\&id=1126

Robert A. Pastor (1999) The Role of Electoral Administration in Democratic Transitions: Implications for Policy and Research, Democratization, Vol.6, No.4, Winter 1999. pp.1-2

Rural Reporters (2015) Nigeria Elections: Council Urge Media to Remain Impartial, March 25. See more at: http://ruralreporters.com/nigeria-elections-council-urge-media-to-remainimpartial// Rural Reporters

Schaffner, B. (2006) 'The Political Geography of Campaign Advertising in U.S. House Elections', Political Geography, Vol. 25, pp. 776

Semetko, Holli A. (2010) Election Campaigns, Partisan Balance, and the News Media, in Pippa Norris (ed.) Public Sentinel: News Media \& Governance Reform, The International Bank for Reconstruction and Development / The World Bank, Available at: http://siteresources.worldbank.org/EXTGOVACC/Resources/PublicSentineleBook.pdf

Sisk, T. (2008). Elections in Fragile States: Between Voice and Violence. Paper prepared for the International Studies Association Annual Meeting San Francisco, California, March 2428 , 2008 http://www.researchgate.net/publication/228464476_Elections_in_Fragile_States_Betwe en_Voice_and_Violence

Stamper, Judith and Brants, Kees (2011) "A Changing Culture of Political Television Journalism" in Brants and Voltmer (eds.) Political Communication in Postmodern Democracy: Challenging the Primacy of Politics, New York, Palgrave Macmillan

Tador, Mediline (2014) 2015 Elections- The Imperative of According Priority to Citizens Issues in Media Reporting. Paper Presented at the Capacity Building Workshop on Election Reporting for Journalists, Organised by the International Press Centre (IPC) in Calabar, Cross River State, 19th - 22nd November 2014

Tettey, Wisdom (2008) Media Pluralism, Democratic Discourses and Political Accountability in Africa, Harvard-World Bank Workshop 29-31st May 2008

UNDP (n.d) E 1 e c t i o n s and Conflict Prevention: A Guide to Analysis, Planning and Programming,

Available

at: 
http://unipsil.unmissions.org/portals/unipsil/media/publications/Elections_and_Conflict_ Prevention.pdf

United Nations Educational, Scientific and Cultural Organization [UNESCO], (2005). "Media and Good Governance". Available at: http://www.unesco.org/new/en/communicationand-information/flagship-project-activities/world-pressfreedom-day/previouscelebrations/worldpressfreedomday200900000/dakar-declaration/

White, Aidan (2014) Turning The Page of Hate: Towards an African Campaign for Tolerance in Journalism, Ethical Journalism Network, April 8 